\title{
The effect of Pilates method on elderly flexibility
}

\section{Efeito do método Pilates na flexibilidade de idosos}

\section{Adriana Coutinho de Azevedo Guimarães ${ }^{[\mathrm{a}]}$, Sabrina Fernandes de Azevedo ${ }^{[\mathrm{b}]}$, Joseani Paulini Neves Simas ${ }^{[c]}$, Zenite Machado ${ }^{[\mathrm{d}]}$, Vanessa Terezinha Ferrari Jonck ${ }^{[\mathrm{e}]}$}

[a] $\mathrm{PhD}$, professor, Universidade do Estado de Santa Catarina (UDESC), Centro de Educação Física e Desportos, Florianópolis, SC - Brazil, e-mail: nanaguim@terra.com.br

[b] MSc, Universidade do Estado de Santa Catarina (UDESC), Departamento de Educação Física, Florianópolis, SC - Brazil, e-mail: saedfisica@hotmail.com

[c] PhD candidate, professor, Universidade do Estado de Santa Catarina (UDESC), Centro de Educação Física e Desportos, Florianópolis, SC - Brazil, e-mail: joseanisimas@gmail.com

[d] PhD, professor, Universidade do Estado de Santa Catarina (UDESC), Centro de Educação Física e Desportos, Florianópolis, SC - Brazil, e-mail: zenite13@yahoo.com.br

[e] Graduate, Universidade do Estado de Santa Catarina (UDESC), Departamento de Educação Física, Florianópolis, SC Brazil, e-mail: ferrari334@hotmail.com

\section{Abstract}

Introduction: Pilates as physical exercise practice brings countless benefits, such as improvement of motor aptitudes and skills. Objective: To look into the effect of the Pilates method on the hip and shoulder girdle flexibility levels in the elderly. Methods: Experimental study composed of 30 elderly subjects of the control group and 30 of the Pilates group within a 12 week training time. A form was used to characterize the sample and to assess hip flexibility and shoulder girdle. Descriptive and inferential statistics were used, under a significance level of $\mathrm{p}<0.05$. Results: On hip flexibility, the 30 elderly individuals from the control group remained under normal and inferior classification, not presenting any differences between the variables $(p=0.180)$ from the pretest to the retest. In the intervention group, $60 \%$ of the elderly subjects were assessed as normal. In the retest, such percentage increased to $66.7 \%$. In the pretest, $10 \%$ of the elderly subjects were given the superior classification, and in the retest, it increased to 33\%, not presenting significance between the variables $(\mathrm{p}=0.180)$. On shoulder flexibility in the intervention group, $63 \%$ of the elderly subjects were graded as normal, and $17 \%$ as superior. In the shoulder retest the number of elderly individuals 
decreased to $47 \%$ in the normal classification, and increased to $33 \%$ in the superior classification, presenting a significant difference $(p=0.001)$. Conclusion: The elderly subjects who did not take part into the Pilates method presented a lower flexibility degree, considering that, the latter reduces in aging. As a preventive way of improving such limitation, the practice of the Pilates method is suggested.

Keywords: Aging. Flexibility. Motor activity.

\section{Resumo}

Introdução: O Pilates como forma de exercício físico propicia inúmeros benefícios, tais como melhora de aptidões e habilidades motoras. Objetivo: Verificar o efeito do método pilates no nível de flexibilidade de quadril e de cintura escapular em idosos. Métodos: Estudo experimental, composto por 30 idosos do grupo controle e 30 do grupo de Pilates com 12 semanas de treinamento. Um formulário foi usado para caracterizar a amostra e aferição da flexibilidade de quadril e de cintura escapular. Utilizou-se estatística descritiva e inferencial, com nível de significância de $p<0,05$. Resultados: Na flexibilidade do quadril os 30 idosos do grupo controle permaneceram na classificação normal e inferior, não apresentando diferenças entre as variáveis $(p=0,180)$ do pré-teste para o reteste. No grupo intervenção $60 \%$ dos idosos obtiveram classificação normal. No reteste, este percentual aumentou para $66,7 \%$. No pré-teste, $10 \%$ dos idosos obtiveram a classificação superior e no reteste, aumentou para 33\%, não havendo significância entre as variáveis $(p=0,180)$. Em flexibilidade de ombro na intervenção, 63\% dos idosos se encontravam na classificação normal e 17\% na superior. No reteste de ombro o número de idosos diminuiu para 47\% na classificação normal e aumentou para 33\% na classificação superior, com diferença significativa $(p=0,001)$. Conclusão: Idosos que não foram submetidos ao método Pilates apresentaram menor grau de flexibilidade, além de esta reduzir com o avanço da idade. Como forma de prevenir e melhorar tais limitações se sugere a prática do método Pilates.

Palavras-chave: Envelhecimento. Flexibilidade. Atividade motora.

\section{Introduction}

Physical, psychological, and social changes are regular events on aging. Such natural process is part of aging, considering a possible variation from each other (1).

The increase of the elderly population is nowadays a demographic reality, more and more extant within the world population (2). Today, Brazil has $8.6 \%$ of its population composed of elderly individuals. Census figures from the Brazilian Institute of Geography and Statistics (IBGE) point at an increasing index probably reaching $13 \%$ by 2020 , and $20 \%$ by 2050 (3), according to such projection, by 2020, Brazil will be ranked sixth in the elderly population rate, considering an over 30 million full population (4).

The combination of preventive habits such as balanced diets, non-smoking routine, decrease of alcohol consumption to acceptable levels, the improvement of body composition, greater movement amplitude, and the control of stress levels might favor the growth of the elderly population, and it has been corroborated by the literature indicating longevity associated with health (5)

The health technology advancement may also contribute to a decrease in mortality rate (6). Furthermore, the elderly participants who practice physical activity tend to show a greater independence, probability, and autonomy, being considered as healthy elderly individuals, even when presenting chronic illnesses. Most part of the chronicle illness of the elderly has its main risk factor in the age itself. Nevertheless, such longevity is not an obstacle for the aged to carry on with their own lives in an autonomous way making decisions on their interests (4).

The skeletal muscle tissue tends to be the most responsive to input, that might justify a more constant demand for muscle aptitude loss observed during aging, and related to lack of muscle use (7). Flexibility is one of the most important physical valences in functional capacity in the elderly, to the performance of 
daily activities, considering a minimum required to enable the elderly a functional autonomy (8).

An option for physical activity practice is the Pilates training, which is a method developed by Joseph Pilates, in the 20's having as bases a concept so called contrology, which means the conscious control of all muscle movement of the body (9).

There are many benefits offered within the method, for instance, strength, flexibility, posture, and motor skills enhancement (10). Positive results have been presented to hamstring muscles on studies using the Pilates method concerning flexibility (11, 12). Another study, with Pilates intervention, twice a week, has shown improvement in dynamic balance, muscle strength and flexibility (13). Therefore, the aim of the present study consisted in verifying the effect of the Pilates method on shoulder girdle and hip flexibility level in the elderly from both genders.

\section{Methods}

The present investigation was characterized as a controlled experimental study of a non-probabilistic sample. Such sample consisted of 60 elderly subjects within the average of $68 \pm 5.1$ years of age, with a predominance of $85 \%$ of females. It was divided into two groups, the first, called Control group, consisted of 30 elderly subjects from the Centro de Atenção a Terceira Idade (CATI), and so called, a living space created by the mayor of São José - Santa Catarina. The second group, called Pilates method intervention, also consisted of 30 elderly subjects who started to participate in the Pilates studio Ivana Henn, at Kobrasol, São José.

The 60 subjects were submitted to the criteria:

a) Control group - not to perform any kind of physical activity during the study and before it throughout a 6 month period;

b) Intervention group - not having performed any physical activity before 6 months, and had never practiced Pilates. The intervention of the Pilates method was carried out with couples for 12 (twelve) weeks, divided into two weekly interventions under 60 minutes of Pilates exercises for each session, always respecting the limits of range of motion of the referred elderly subjects. The following tools were used in the interventions: Cadillac; Reformer; Chair;
Barrel, and floor (for the stretching, trunk flexion and extension series at the Cadillac, fixed and flying trapeze; variation of hip flexion and extension with springs; variation of trunk lateral flexion and extension at the fixed trapeze; ankle flexion and extension; trunk rotation and abdominals series). The following accessories were also used: Over Ball, Magic circle, Toning Ball, roller, Swiss ball; and in other sessions there was no accessories application.

The study was approved by the Committee on Ethics for Human Beings at the Universidade do Estado de Santa Catarina, on 02/09/11, protocol n. $255 / 2010$. All elderly subjects who accepted to take part in the study signed a Free and Clarified Consent Term.

For the data collection a form was used as a tool in identifying gender, age, marital status, schooling, illnesses, medicine, and economic stratum (14), main tool to assess the economic strata in Brazil which classifies the population into classes A, B, C, D, and E.

For the hip flexibility assessment the sit and reach test was carried out, in which the elderly sit at the seat edge flex a knee, keep the foot completely on the floor, and the other leg (under evaluation) outstretched with the heel on the floor and the ankle in dorsiflexion position. Into such initial position, the elderly should slowly slide the hands along the outstretched leg, trying to touch the toes, considering it is necessary the use of a straight back chair and a $45 \mathrm{~cm}$ ruler for measuring, as in Figure 1. The behind-the-back reach test was used for the shoulder girdle flexibility. In this procedure the elderly must put the dominant hand over the same shoulder and try to reach as low as possible towards the middle of the back, keeping the stretched fingers touching the back. The other hand must be under and behind it, with the back of the hand touching the back, reaching as far as possible, trying to touch or overlap the middle fingers from both hands, by the use of a $45 \mathrm{~cm}$ ruler as illustrated in Figure 2 (15). The results of the flexibility test will be assessed following normative values developed for the elderly (16).

\section{Description of the Pilates method intervention}

The 60 minute training sessions were carried out twice a week for 12 weeks, in pairs, firstly at a 
beginner level, then, upgrading to the intermediate level, according to the limits of range of motion and developing for each subject. The following specific machinery was used during the study: Reformer, Cadillac, Wunda-chair, Barrel, Wall, as well as exercises with and without the use of machines (Mat). The following accessories were introduced in both cases: over ball, Thera-band, step barrel, magic circle, Swiss ball, rollers, half-moon barrel and sitting box, aiming to make the exercises more intense, difficult and diversified. For each session the intensity of the exercises varies from medium to moderate, considering series of 10 to 12 repetitions for each exercise, in which the following physical valences were aimed at: strength, flexibility, and resistance.

\section{Data analysis}

Data analysis was carried out using SPSS version 16.0. We used the descriptive statistics (average, standard deviation, and percentage) to characterize the sample and the inferential, through the Chi-square test to compare flexibility between the groups. The

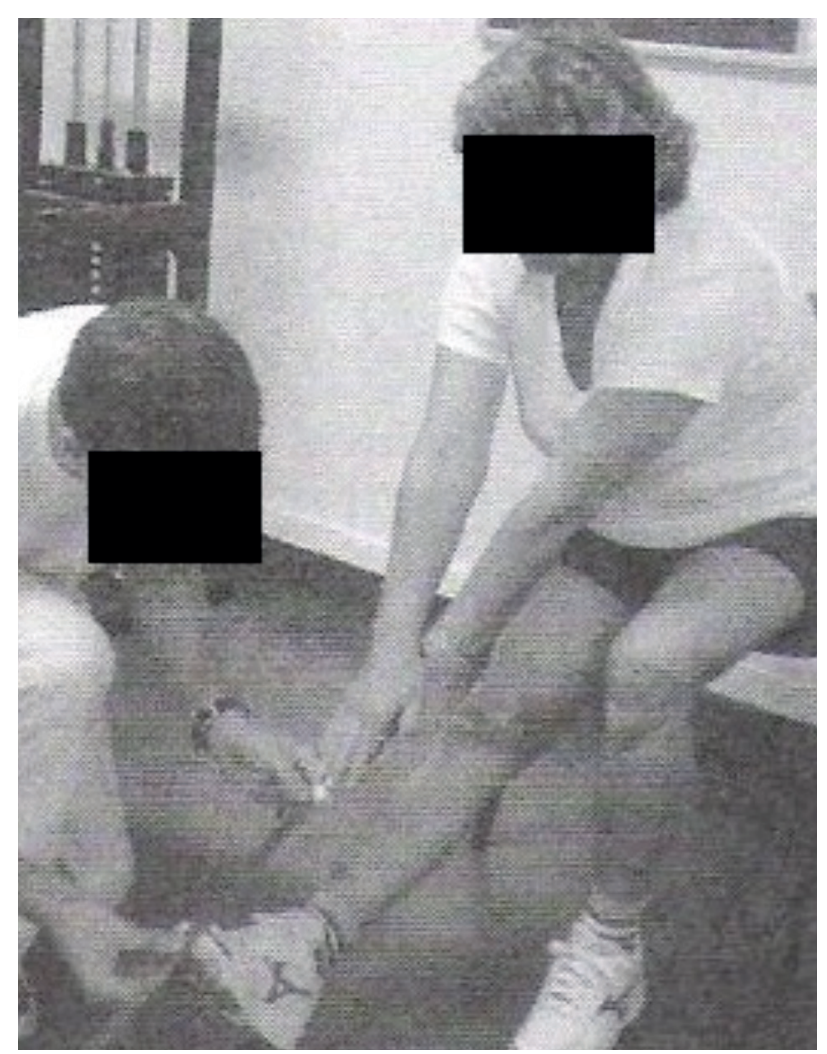

Figure 1 - Sit and reach test

Source: Rikli and Jones (15). level of statistical significance was established for $\mathrm{p}<0.05$.

\section{Results}

The sample is composed of 43 widowers, followed by 37 married elderly subjects, considering most of the economic stratum B and C (38\%). Concerning the pathological trait, most of the subjects suffer from hypertension, among other diseases such as coronary heart disease and diabetes, from which $75 \%$ makes use of medications as angipress, captopril, hydrochlorothiazide, atenolol, methyldopa, ramipril, lithium carbonate, lisinopril, simvastatin, amiodarone, propatilnitrato, metformin, insulin, among others.

Table 1 shows test and retest results on elderly hip and shoulder girdle flexibility, set into control and intervention group. Concerning hip flexibility, the 30 elderly subjects from the control group remained under normal and inferior classification, not presenting any differences between the variables assessed ( $p$ $=0.180$ ). Nevertheless, from the intervention group, $60 \%$ was considered normal; such percentage was

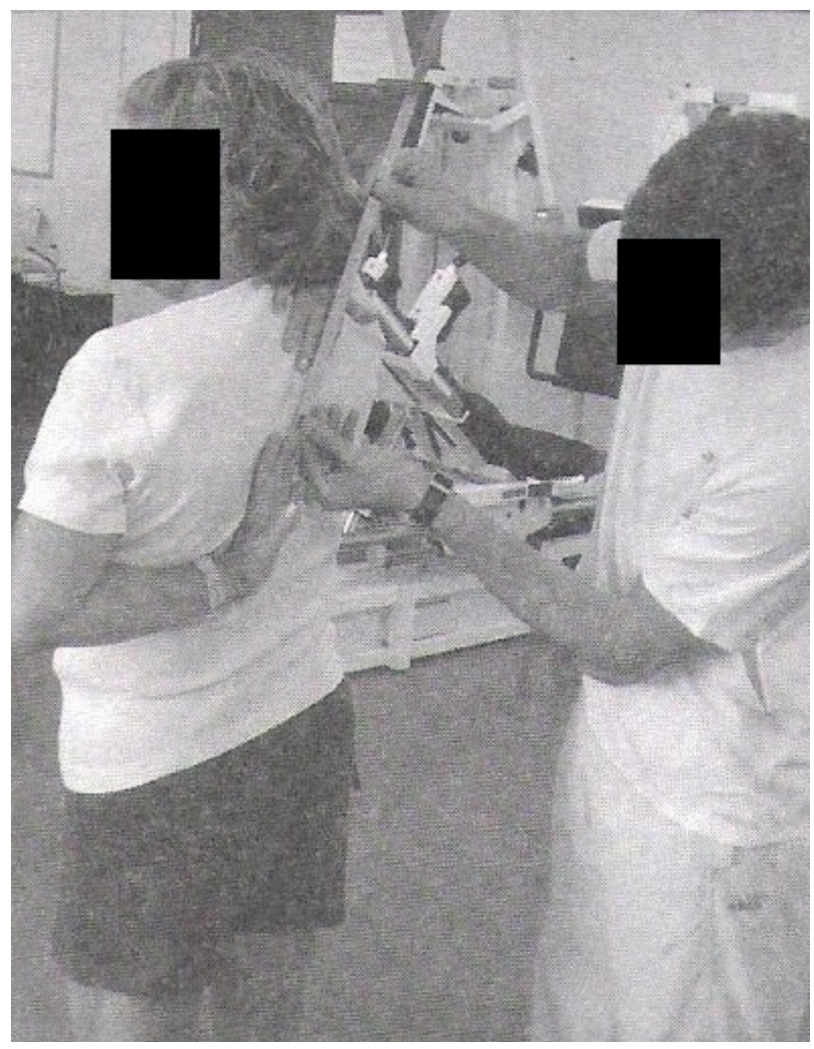

Figure 2 - Reach behind the back Source: Rikli and Jones (15). 
raised to $66.7 \%$ in the retest. In the superior classification we had $10 \%$, however, in the retest there was a rise of $33.3 \%$, not having significance between the variables $(p=0.180)$, though.

Still in the intervention group, on shoulder girdle flexibility, $63.3 \%$ of the elderly subjects were classified under normal, and $16.7 \%$ on superior flexibility, changing this number to $46.7 \%$ in normal classification, and to $33.3 \%$ on the superior classification on the retest, within an increase of $16.6 \%$ for the superior variant on the retest, with significant difference between the variables $(p=0,001)$.

Table 1 - Flexibility levels of the elderly subjects in the study

\begin{tabular}{|c|c|c|c|c|c|}
\hline \multirow{2}{*}{ Variables (\%) } & \multicolumn{2}{|c|}{ Control } & \multicolumn{2}{|c|}{ Intervention } & \multirow{2}{*}{ P Value } \\
\hline & Test & Retest & Test & Retest & \\
\hline Hip Flexibility & & & & & 0.180 \\
\hline Superior & - & - & 10.0 & 33.3 & \\
\hline Normal & 60.0 & 53.3 & 60.0 & 66.7 & \\
\hline Inferior & 40.0 & 46.7 & 30.0 & - & \\
\hline $\begin{array}{l}\text { Shoulder Girdle } \\
\text { Flexibility }\end{array}$ & & & & & $0.001^{*}$ \\
\hline Superior & 3.3 & - & 16.7 & 33.3 & \\
\hline Normal & 36.7 & 40.0 & 63.3 & 46.7 & \\
\hline Inferior & 60.0 & 60.0 & 20.0 & 20.0 & \\
\hline
\end{tabular}

Note: A comparison between the control and the intervention groups. ${ }^{*}=$ significant for $p<0.05$.

Source: Research data.

\section{Discussion}

In our study as well as in others $(11,17)$, there was a predominance of females both in the control and the intervention group. This fact can be confirmed in accordance with the studies of $(18,19)$, which found that in Brazil there is a higher prevalence of elderly women and that this difference increases within the aging process. This fact becomes evident and may be attributed to a greater tendency for self-care, less exposure to external agents of greater risk to health such as smoking, alcohol use, occupational factors and greater medical assistance (20), in his study, adds that the reason for the demand for Pilates is greater among women due to therapeutic and aesthetic problems. Studies have shown that the lack of demand for physical activity is greater in men than in women, and it may be explained by cultural grounds (11). The female demand for physical activity may be because they are more susceptible to the aging effects (menopause and its symptoms), arousing in them the psychological aspect of seeing themselves less attractive and dissatisfied with their own bodies (17). Regarding the socioeconomic status (21) indicates that most of the practitioners of the Pilates method belongs to the upper middle class, which corroborates with our study, in which the more active elderly subjects are most of the economic stratum B. This fact may be related to having a more relatively comfortable economic situation making it possible the practice of the Pilates method. The same author points out that the Pilates practitioners, within this situation, have less chance to interrupt the activity due to financial issues.

Due to the fact that the practice of the Pilates method needs a professional to guide the correct way of practice, the number of practitioners is lower when compared to other methods, which makes it more expensive, but more individualized, giving the practitioner a way to receive all the benefits that the method can provide (22). Such factors may interfere with the elderly of $\mathrm{C}$ classification in search for this modality. 
The intervention group, relatively healthy in our study because of the natural process of aging, demonstrated to know how to cope with their diseases (chronic-degenerative diseases such as hypertension, with greater occurrence, followed by coronary heart disease and diabetes), although it does not prevent the practice of the Pilates method. In relation to the health conditions, in a study similar to ours, it was found that most of the elderly practitioners of the Pilates reported health problems (60\%), being the most common pathology the systemic arterial hypertension/SAH, thus reinforcing our study in which such pathologies do not prevent the practice of the Pilates method (23). The study (19) pointed out that, hypertensive elderly patients recognized that with the inclusion of physical activity and diet in their daily life there was a positive result in the control of hypertension.

Studies show that the elderly, who practice physical activity, tend to have a greater probability of independence and autonomy and an they can be considered healthy elderly subjects, although they should present one or more diseases, even the chronicle ones. The greater part of the chronic disease of the elderly has its main factor of risk in the age itself.

Nevertheless, such longevity is not preventing the elderly to carry their own life in an autonomous way, deciding about their interests $(4,24)$. The elderly are attempted for anatomo-physiological changes, such as: bone mass and muscle mass loss (sarcopenia), strength reduction, low flexibility, slowness in the performance of movements and frequent standing body oscillation, considering possible postural alteration due to the oscillation (25). This situation can be prevented and minimized whether the elderly are submitted to a regular strength and flexibility program, avoiding even home falls which are common in that age. Flexibility is essential to the functional capacity of the elderly, mainly during the performance of daily activities, in which it is necessary a minimum of such physical valence required for a functional authonomy (26).

In this study, hip and shoulder girdle flexibility were verified by the sit and reach, and reach behind the back tests and retests, in which after 12 weeks the control group did not present improvement in hip and shoulder flexibility, considering that in some cases the retest even showed a decrease in such flexibility. However, in the intervention group, after the same period of time with two weekly Pilates sessions in the retest, positive alterations were registered for the sit and reach, and reach behind the back, it showed significant improvement in shoulder girdle flexibility. In intervention studies with strength components, in weekly sessions varying from 2 to 3 days, from 8 to 16 weeks, we noticed that the participants had and improvement of both shoulder girdle and hip flexibility $(25,27,28)$. Besides, a study using the Pilates method showed that the practice of the method, in two sessions of 60 weekly minutes, in a 12 week period, presented positive alterations in hamstring and upper body flexibility (12). Another study, also within a 12 week period, with two weekly Pilates intervention, showed improvement in dynamic balance, muscle strength, and flexibility, resulting in a decrease in falls from elderly female subjects (13).

Thus, a satisfactory demonstration of flexibility is relevant, because, due to the aging process the articular movements suffer changes. Fernandes in agreement with Benedetti affirm about the importance that flexibility has to shoulder abduction and its influence on daily activities such as taking a shower, for instance, you need shoulder abduction $170^{\circ}$; for washing the back, it is necessary a $130^{\circ}$ angle (29, 30 ). For dressing a pair of pants or socks you need $60^{\circ}$ (hip), and the use of the toilet takes a $40^{\circ}$ angle (hip and shoulder girdle).

Pilates is a training method that has as its basis the local muscle strengthening in the central body area (abdominal, paravertebral, gluteus maximus, and pelvic floor muscles), named after its creator Joseph Pilates as a powerhouse (10). It unites posture control, the body stability, and an improved motor development to the strengthening of these muscles and improve flexibility (31).

There are some studies that are intended to reinforce the Pilates method philosophy and its benefits. In a study with the objective of evaluating the effects of the Pilates method on the functional autonomy of the elderly, tests of functional mobility were applied to a group of elderly women and then, the group was divided into intervention and control groups, considering that the intervention group underwent the Pilates method practice. After eight weeks a significant functional improvement was noticed for the elderly women (10). Another study on the basis of the Pilates method tried to assess the effects of this method on the abdominal muscle, lumbar strength, muscular abdominal resistance, and trunk posterior flexibility, together with the physical composition of sedentary women. It 
is possible to conclude that there was a positive answer in all cited areas, regardless of the fact that the weight and body fat percentages did not differ significantly (32). Besides the studies above, another study inspired in the Pilates method, with the intention of checking the balance in the vertical position (known as postural stability in the elderly), showed that after eight weeks of training, they presented a significant improvement inducing the reduction of fall risks (33). Therefore, the benefits of the Pilates method concern the strength improvement, flexibility, posture and motor skills. Besides, it provides a reunion with the corporation itself, making it possible for the individual to recover part of his lost independence, providing them a better quality of life.

Within this context, the present study found that the results do not differ from those found in the literature. It is possible to conclude that the elderly who do not practice any type of oriented physical activity on a regular basis tend to have a lower degree of flexibility, beyond what is naturally reduced in the aging process. Nevertheless, as an appropriate manner of preventing and improve in a significant way this limitation, inducing a greater functional mobility, the practice of the Pilates method training is suggested.

\section{Referênces}

1. Cruz RC, Ferreira MA. Um certo jeito de ser velho: representações sociais da velhice por familiares de idosos. Texto Contexto - Enferm. 2011;20(1):144-51.

2. Carvalho J, Soares JMC. Envelhecimento e força muscular: breve revisão. Rev Port Cien Desp. 2004;4(3):79-93.

3. Ferreira CG, Alexandre TS, Lemos ND. Fatores associados à qualidade de vida de cuidadores de idosos em assistência domiciliária. Saude Soc. 2011;20(2):398-409.

4. Veras R. Envelhecimento populacional contemporâneo: demandas, desafios e inovações. Rev Saúde Públ. 2009;43(3):548-54.

5. Cabral RLM, Dantas PMS, Montenegro Neto AN, Knackfuss MI. Efeitos de diferentes treinamentos e estilos de vida nos indicadores antropométricos e cardiocirculatórios no envelhecimento. Rev Salud Pública. 2009;1(3):359-369.
6. Patrício KP, Ribeiro H, Hoshino K, Bocchi SCM. O segredo da longevidade segundo as percepções dos próprios longevos. Ciênc Saúde Coletiva. 2008;13(4):1189-98.

7. Geraldes AAR, Dias Júnior NM, Albuquerque RB, Carvalho J, Farinatti PTV. Efeitos de um programa de treinamento resistido com volume e intensidade moderados e velocidade elevada sobre o desempenho funcional de mulheres idosas. R Bras Ci e Mov. 2007;15(3):53-60.

8. Varejão RV, Dantas EHM, Matsudo SMM. Comparação dos efeitos do alongamento e do flexionamento, ambos passivos, sobre os níveis de flexibilidade, capacidade funcional e qualidade de vida do idoso. R Bras Ci e Mov. 2007;15(2):87-95.

9. Kolyniak IEG, Cavalcanti SMB, Aoki MS. Avaliação isocinética da musculatura envolvida na flexão e extensão do tronco: efeito do método Pilates. Rev Bras Med Esporte. 2004;10(6):487-90

10. Rodrigues BGS, Cader SA Torres NVOB, de Oliveira EM, Dantas EHM. Autonomia funcional de idosas praticantes de Pilates. Fisioter Pesq. 2010;17(4):300-5.

11. Lima PSQ, Medeiros MSL, Mendes ACG, Laurentino GEC, Montenegro EJN. 0 método Pilates no ganho de flexibilidade dos músculos isquiotibiais em pacientes portadores de hérnia de disco lombar. Fisiot Bras. 2009;10(5):314-7.

12. Kloubec JA. Pilates for improvement of muscle endurance, flexibility, balance, and posture. J Strength Cond Res. 2010;24(3):661-7.

13. Irez GB, Ozdemir RA, Evin R, Irez SG, Korkusuz F. Integrating Pilates exercise into an exercise program for $65+$ year-old women to reduce falls. J Sports Sci Med. 2011;10(1):105-11.

14. Associação Brasileira de Empresas de Pesquisa. Critério de classificação econômica Brasil. São Paulo: ABEP; 2010.

15. Rikli RE, Jones CJ. Development and validation of a functional fitness test for community-residing older adults. JAPA. 1999;7(2):129-61.

16. Rikli RE. Reliability, validity, and methodological issues in assessing physical activity in older adults. Res Q Exerc Sport. 2000;71(2 Suppl):S89-96. 
17. Pereira RJ, Cotta RMM, Franceschini SCC, Ribeiro RCL, Sampaio RF, Priore SE, et al. Contribuição dos domínios físico, social, psicológico e ambiental para a qualidade de vida global de idosos. Rev Psiquiatr Rio Gd Sul. 2006;28(1):27-38.

18. Garcia RA, Carvalho, JAM. 0 envelhecimento da população brasileira: um enfoque demográfico. Cad. Saúde Públ. 2003;19(3):725-733.

19. Zaitune MA, Barros MBA, César CLG, Carandina L, Goldbaum M. Hipertensão arterial em idosos: prevalência, fatores associados e práticas de controle no município de Campinas, São Paulo, Brasil. Cad Saúde Pública. 2006;22(2):285-94.

20. Neutzling M, Mello L, Vianna M, Morales Morales M, Haas R, Giusti, P. Motivos que levam as mulheres a prática do método Pilates em quatro clínicas da cidade de Pelotas. In: Anais do 21. Congresso de Iniciação Científica e 4. Mostra Científica, 2012, 1-4 nov. Pelotas: Universidade Federal de Pelotas, 2012.

21. Pinton, LB, Franco ACSF. Influência do método pilates: uma proposta de atividade física. Coleç Pesqui Educ Fís. 2007;5(1):345-50.

22. Rosa KB, Liposcki D, Waltrick T, Slongo A. Qualidade de vida e avaliação funcional em idosos praticantes de pilates e idosos sedentários. RIES. 2013;2(1):18-28. Estudos em Saúde

23. Reis LA, Mascarenhas CHM, Lyra JE. Avaliação da qualidade de vida em idosos praticantes e não praticantes do método pilates. C\&D-Revista Eletrônica da Fainor. 2011;4(1):38-51.

24. Sacco ICN, Andrade MS, Souza OS, Nisiyama M, Cantuária AL, Maeda FYI, et al. Método Pilates em revista: aspectos biomecânicos de movimentos específicos para reestruturação postural: estudos de caso. R Bras Ci e Mov. 2005;13(4):65-78.

25. Lima HCO, Aguiar JB, Paredes PFM, Gurgel LA. Avaliação dos benefícios da ginástica localizada sobre a postura e a flexibilidade de mulheres na terceira idade. Rev Bras Educ Fís Esporte. 2010;24(4):525-34.
26. Beck AP, Antes DL, Meurer ST, Benedette TRB, Lopes MA. Fatores associados às quedas entre idosos praticantes de atividades físicas. Texto Contexto - Enferm. 2011;20(2):280-6.

27. Vale RGS, Barreto ACG, Novaes JS, Dantas EHM. Efeitos do treinamento resistido na força máxima, na flexibilidade e na autonomia funcional de mulheres idosas. Rev Bras Cineantropom Desempenho Hum. 2006;8(4):52-8.

28. Gonçalves J, Zago E, Nodari C, Pires Neto CS. Influência do exercício físico na auto estima, auto imagem e auto eficácia de idoso do município de Videira, SC. Rev Bras Ativ Fís Saúde. 2007;12(2):125.

29. Fernandes S, Guimarães ACA, Machado Z, Simas JPN. Flexibilidade de cardiopatas praticantes e não praticantes de atividade física. R Bras Ci Saúde. 2011;14(4):37-44.

30. Benedetti TRB, Petroski EL. Idoso asilado em prática de atividade física. Rev Bras Ativ Fís Saúd. 1999; $4(3): 5-16$

31. Curnow D, Cobbin D, Wyndham J, Choi STB. Altered motor control, posture and the Pilates method of exercise prescription. J Bodyw Mov Ther. 2009;13:104-11.

32. Sekendiz B, Altuna O, Korkusuza B, Akinb S. Effects of Pilates exercise on trunk strength, endurance and flexibility in sedentary adult females. J Bodyw Mov Ther. 2006;11:318-26.

33. Kaesler DS, Mellinfont RB, Swete K, Taaffe DR. A novel balance exercise program for postural stability in older adults: a pilot study. J Bodyw Mov Ther. 2007;11:37-43.

Received: 09/18/2013

Recebido: 18/09/2013

Approved: 04/30/2014

Aprovado: 30/04/2014 